\title{
Comment on "Sraffa and the Labour Theory of Value: a note" - Reply to William Jefferies
}

\author{
Comentário sobre "Sraffa Sraffa e a Teoria do Valor \\ do Trabalho: uma nota": resposta a William Jefferies
}

FABIO ANDERAOS DE ARAUJO****

RESUMO: Esta é uma resposta às críticas levantadas por William Jefferies (Jefferies, 2020) ao meu artigo "Sraffa e a Teoria do Valor do Trabalho: uma nota" (Araujo, 2019). Em Jefferies (2020), o autor deu grande ênfase à questão da comensurabilidade física entre insumo e produto no modelo de preços de Sraffa.

PALAVRAS-CHAVE: Valor-trabalho; preço; comensurabilidade; mercadoria-padrão.

ABSTRACT: This is a reply to the criticisms raised by William Jefferies (Jefferies, 2020) to my article "Sraffa and the Labour Theory of Value: a note" (Araujo, 2019). In Jefferies (2020) the author has given great emphasis to the question of physical commensurability between input and output in Sraffa's price model.

KEYWORDS: Labour-value; price; commensurability; standard commodity.

JEL Classification: B12; B51.

\section{INTRODUCTION}

It is with great pleasure I receive the criticism from Jefferies (2020) to my article (Araujo, 2019). As interesting questions are raised in his criticisms, they are an excellent opportunity to reaffirm the logical consistency of Sraffa's model to solve both the determination of prices and income distribution, that is, to move away definitively every subjective or arbitrary postulate of invariance, that is, a numeraire invariant to changes in distribution.

Besides the detailed mathematical explanation of the postulate of invariance

\footnotetext{
* Autonomous economic researcher, São Paulo/SP, Brazil. E-mail: fanderaos@gmail.com. Orcid: https:// orcid.org/0000-0003-1910-489X. Submitted: 23/July/2020; Approved: 24/July/2020.

** During the preparation of this reply to William Jefferies, I received useful and invaluable comments and suggestions from both Andrés Lazzarini (Goldsmiths, University of London, UK) and Luiz Antonio de Oliveira Lima (Getulio Vargas Foundation, São Paulo, Brazil). However, any mistake or misunderstanding is of my entire responsibility.
} 
proposed by Sraffa, that is, the Standard Commodity (Araujo, 2019, p.621-624 and in Appendix I, p.628-631), I firmly believe it is necessary to provide additional comments on the logical structure of Sraffa's model.

A postulate of invariance or numeraire is subjective if its correspondent value was arbitrarily chosen, like the price of one ounce of gold, for instance. The intrinsic value of gold $(99,99 \%$ purity) may change due to several factors, like advances in technology to produce it, geopolitical conditions etc. The real purpose of a postulate of invariance is twofold. First, to provide an additional equation to equalize the number of unknows with the number of independent equations and secondly, make the determination of absolute prices, not relative prices and distribution feasible.

The simplest postulate of invariance is when the price of an arbitrarily chosen commodity is equal to unit, that is, $p_{i}=1$. The price $p_{i}$ could be the price of one bushel of wheat, or of one ton of wheat flour or of one kilogram of bread or of a physical quantity of any other commodity. In a price system with $n+2$ unknowns ( $\mathrm{n}$ prices, $\mathrm{r}$ and $\mathrm{w}$ ) and $\mathrm{n}$ independent equations, this type of postulate of invariance provides an additional independent equation and all other commodities prices will be expressed in terms of $\mathrm{p}_{\mathrm{i}}$. For instance, if $\mathrm{p}_{\mathrm{a}}=1$ and $\mathrm{p}_{\mathrm{b}}=3$, this means that one unit of commodity " $b$ " is exchangeable for three units of commodity " $a$ ". However, it is necessary one more independent equation to determine the $(n+1)$ unknowns.

For those interested on the subject, I suggest reading the classical article of Francis Seton (1957), where he discusses the main postulates of invariance proposed by both Marx and Marxian economists.

The great merit of Sraffa was to provide a new postulate of invariance, the Standard Commodity, which emerges from the own system of equations of production. Such numeraire was endogenously determined, unlike that proposed by others classical and Marxian economists, who took the numeraire exogenously. In building the Standard Commodity, there is not any element or trace of subjectivity.

According to the Labour Theory of Value, the total quantity of abstract labour equals the value of the net national income. In Sraffa's model this proposition is very clear, because

$$
\mathrm{p}(\mathrm{B}-\mathrm{A}) \mathrm{Q}=\mathrm{LQ}=1
$$

Sraffa's model would not be complete if there was not any logical correspondence between physical quantities of commodities and their respective labour values. Such linkage is given by Sraffa in the chapter VI of his book, with the method of Reduction to Dated Quantities of Labour. With such a method it is possible to demonstrate that a price of a commodity is an infinite series of direct and indirect quantities of labour embodied through time across present and past rounds of production.

But in the Introduction of his critique to my article, Jefferies states that “...why bother with labour values if a logically superior alternative exists?” (Jefferies, 2020, p.1). To address his concerns, let us move to the issue of commensurability. 


\section{THE QUESTION OF COMMENSURABILITY}

Jefferies is of course, referring to Sraffa's price equations.

In such equations there is a physical commensurability between inputs and outputs. On Araujo (2019, p.626) I expressly stated that “...in the real world, commensurability is an exception, not the rule, because production leads to transformation".

However, it is not because the physical commensurability between inputs and outputs does not represent the bulk of production of goods in modern and industrialized economies, that it must be neglected in the determination of both the production prices and distribution of income between wages and profits.

Let me introduce a simple but real example to illustrate my above comment.

In the production of fine pocket and wrist mechanical watches made by artisans in Switzerland, Germany or Japan, the calibre or the mechanical movement is constituted by many components. Even a tiny screw is considered a component. In general, the greater the number of complications, the greater the number of components. In the watchmaking universe, chronograph, perpetual calendar, moon phase, equation of time and any other astronomical indication is considered a complication. One of the most admired astronomical indication is the "running equation of time" (équation marchante), which provides the movement of the real solar time during a time period, say, one year, for instance. Considering that the Earth makes an elliptical orbit around the Sun, the real solar time is not regular as the "mean solar time", created by Man. The movement of the Earth around the Sun has the format of a pear fruit, not exactly round as the conventional mean solar time. During the year, only in four dates of the Gregorian calendar does the real solar time coincide with the mean solar time. In order to reproduce this elliptical movement of the running equation of time, watch artisans introduced a small metallic device, accurately manufactured and much simpler than the complex escapement, for instance, considered the heart of any mechanical watch.

In the above example the reader must have noticed the analogy among the existence of physical commensurability in the production of commodities with the device of the running equation of time. Without this simple mechanical device, it would not be possible to show the real solar time on the dial of the watch. The same conclusion is valid for the physical commensurability between inputs and outputs in the production of commodities.

Considering that non-basic commodities are the bulk of the production in modern economies, without the physical commensurability between inputs and outputs it is not possible to determine the price of the primary components of the cost of production of that non-basic commodities (Araujo, 2019, pp. 626-627). No production system can get rid of this class of commodities.

Jefferies reduces the production process to a mere physical transformation of "inputs from one, less useful, form into another, more useful, form" (Jefferies, 2020, p.1). He also states that "This means that physical production is incommensurate". I suspect that Jefferies was not entirely sure of his latest statement. In order to be 
coherent with his reasoning, the correct phrase would have been "... all physical production is incommensurate".

Since Jefferies does not explain how the inputs in their more concise and simple physical form were introduced in both the production and price systems, his conception of production is limited and very similar to that of the neoclassical approach: physical inputs are mere endowments in the production process. Jefferies takes as granted the inputs, which he names less useful, that will be transformed "into another, more useful, form".

Jefferies identifies inputs as only original factors, like land and labour, for instance and he totally misses the point that inputs are also outputs.

Also, when Jefferies talks about "usefulness" or "uselessness" this does not make any sense from the point of view of production: the techniques of production are given, namely: they are the result of the observation by Sraffa, as well as Ricardo and Marx of the black boxes in which inputs (physical inputs, the wage goods of labourers etc.) flow in from one side and outputs flow out from other side. It is a materialistic methodological standpoint.

On page 2 of Jefferies criticism there is another point worth mentioning. $\mathrm{He}$ criticizes Marx's procedure of transformation of labour values into prices of production. For Jefferies "Marx's transformation procedure is mathematically inconsistent because it is consistent with reality" (Jefferies, 2020, p.2, italics added).

Jefferies is traying to play with words. The above statement from Jefferies does not prove anything and it is a wordy declaration of surrender on his part.

If we grant the benefit of the doubt, it is a case of asking: which reality does Jefferies refer to?

Additionally, Jefferies does not provide any alternative solution to the transformation problem of labour values into prices of production.

\section{FINAL REMARKS}

On (Jefferies, 2019, p.3), Jefferies criticises that Sraffa's theory rests on three essential properties:

1) the qualitative identity between inputs and outputs, which "contradicts the purpose of production ...";

2) "that relative prices are fixed, this contradicts to the purpose of capitalist production, ...";

3) "that surplus appears from nowhere or without equivalent, this contradicts the human basis of human production".

Regarding the first aspect, I believe it was sufficiently addressed in the preceding pages of my reply.

As to the second statement, it is not clear why Jefferies assumes relative prices are fixed in Sraffa's model. On chapter VI of his book, section 48, Sraffa pro- 
vides a numerical example of the non-linear movement of relative prices as the distribution between wages and profits changes, considering the range $0<\mathrm{w}<1$. It is surprising Jefferies made such assumption, since he has grasped the method Reduction to Dated Quantities of Labour (Sraffa, 1960, chapter VI).

Finally, physical surplus is the result of the production process. In each price equation there is a technique of production representing the combination of means of production and labour (technical coefficients) for each industry output.

In order to reproduce the social system, it is necessary at least produce the same level of last period, that is, at least the minimum of subsistence plus inputs. However, since nothing prevents technical progress from allowing an increase in productivity, then a surplus will be expected. In Sraffa, it is not determined in advance to whom this surplus belongs, because it is a social phenomenon and as such it is society that decides how to distribute it.

In other words, in Sraffa's price system there is plenty of room to incorporate institutions, economic policies, wage negotiations etc., into the determination of distribution, as so was for the classical political economists and Marx.

\section{REFERENCES}

de Araujo, Fabio Anderaos (2019) "Sraffa and the Labour Theory of Value: a note". Brazilian Journal of Political Economy, 39 (4) (157): 614-637.

Jefferies, William (2020) "Comment on Sraffa and the Labour Theory of Value - a note". Brazilian Journal of Political Economy, (to be published with the Reply from Fabio ...)

Seton, Francis (1957) “The Transformation Problem". Review of Economic Studies, vol 24, pp.149160. The article was also published in Economics of Marx - M. C. Howard and J. E. King, Penguin Books, England, 1976, pp. 162-176.

Sraffa, Piero (1960) "Production of Commodities by Means of Commodities - Prelude to a Critique of Economic Theory”. Cambridge: Cambridge University Press. 